Artur Mudrecki*

\title{
Modele sądowej ochrony praw podatnika w świecie - wybrane zagadnienia
}

\section{Zarys modeli ochrony praw podatnika}

Przestrzeganie praw podatnika przed organami administracji podatkowej, aby było skuteczne, musi być zagwarantowane sądową kontrolą postępowania podatkowego. Z kolei nadzór sądu w procesie odwoławczym od indywidualnych aktów administracyjnych jest jednym z kanonów demokratycznego państwa prawnego. W szeroko rozumianym postępowaniu podatkowym podatnik powinien mieć zagwarantowane prawo do sądu, tj. prawo do złożenia skargi.

W świecie występują bardzo różnorodne modele ochrony sądowej praw podatnika. Podział tych modeli i przedstawienie najważniejszych sposobów postępowania w poszczególnych krajach pozwoli wstępnie odpowiedzieć na pytanie, jak funkcjonuje i jaka jest organizacja sądownictwa podatkowego. Poza tym można pokusić się o dokonanie oceny, czy przyjęte rozwiązania gwarantują podatnikowi prawo do rzetelnego procesu i wydawania przez sędziów sprawiedliwych i rozsądnych wyroków.

Model - to inaczej wzór, według którego coś jest wykonywane ${ }^{1}$. Generalnie modele sądowej ochrony praw podatnika są bardzo zróżnicowane ze względu na tradycje występujące $\mathrm{w}$ danym państwie, przyjęte systemy prawne i możliwość wyboru przez każde państwo procedury sądowoadministracyjnej w ramach autonomii proceduralnej. Poza tym modele te mogą mieć charakter mieszany.

W sprawach podatkowych można wyodrębnić specyficzne cechy, które odróżniają je od innej kategorii spraw. Po pierwsze, podmiotem zwracającym się o ochronę są podatnicy, którzy chcą uzyskać zmianę rozstrzygnięcia zapadłego przed organami administracji podatkowej. Przedmiotem kontroli sądowej jest wykładnia przepisów materialnego prawa podatkowego, które wymagają specyficznej wykładni, chociażby ze względu na zasadę autonomii prawa podatkowego.

* Dr Artur Mudrecki - Katedra Prawa Finansowego i Podatkowego, Kolegium Prawa, Akademia Leona Koźmińskiego w Warszawie.

${ }^{1}$ E. Sobol (red.), Maty stownik języka polskiego, Warszawa 1997, s. 449. 
Ponadto, w niektórych państwach kognicji sądowej poddane zostały indywidualne interpretacje podatkowe (np. Polska). Bardzo często przyjęta procedura podatkowa jest odmienna od procedury administracyjnej. A zatem rozstrzygnięcie spraw podatkowych wymaga wiadomości szczególnych i co najmniej specjalizacji organów sądowych podejmujących się rozstrzygania tych spraw.

Ze względu na umiejscowienie sądownictwa podatkowego można wyróżnić następujące modele:

- model sądowej ochrony praw podatnika, zagwarantowany przez wyspecjalizowane sądy finansowe (Niemcy, Portugalia, Kanada, Nigeria);

- model ochrony praw podatnika w ramach sądownictwa administracyjnego (Polska, Austria, Francja);

- model sądowej kontroli, działający w ramach sądownictwa powszechnego (Holandia);

- model mieszany sądownictwa, działający w ramach sadów powszechnych z ostatnią instancją wyspecjalizowanego sądu administracyjnego (Czechy).

Oprócz tego w ramach ochrony praw podatnika działają quasi-sądy podatkowe (Dania), które wspomagają kontrolę decyzji organów podatkowych. Jednak w tym wypadku podatnik zazwyczaj ma prawo wyboru sposobu ochrony i może skorzystać z ochrony zagwarantowanej przez sądy.

Z. Kmieciak zwraca uwagę na wewnętrzną niejednolitość orzekania, tj. dualizm jurysdykcji sprawowanej przez sądy administracyjne w sprawach podatkowych. Wskazuje on na model pełnego orzekania oraz model orzekania weryfikacyjnego, co do zasady kasacyjnego. W pierwszym przypadku mamy do czynienia $\mathrm{z}$ ochroną praw podmiotowych, a w drugim $-\mathrm{z}$ ochroną obiektywnego porządku prawnego. W modelu pełnego orzekania sąd jest władny wzruszyć zaskarżony akt i zastąpić go własnym orzeczeniem. Częściej stosowany jest tryb rewizyjny, który prowadzi do oceny legalności zapadłego aktu administracyjnego². Ze względu na zakres kontroli i sposób zakończenia postępowania sądowego można wyróżnić model merytoryczny (Francja, Wielka Brytania) i model kasacyjny (Polska, Austria). Model orzekania kasacyjnego oparty jest na trójpodziale władz, bowiem swoimi orzeczeniami nie rozstrzyga merytorycznie i nie wnika w kompetencje władzy wykonawczej. Jednak może on prowadzić do znacznego wydłużenia postępowania. Natomiast model merytoryczny orzekania zazwyczaj występuje w trójinstancyjnym sądownictwie i znacznie przyspiesza czas załatwienia sprawy. W aktualnie przesłanym przez Prezesa NSA do Prezydenta RP projekcie ustawy o zmianie ustawy Prawo o postępowaniu przed sądami administracyjnymi zaproponowano pewne zmiany pozwalające sądowi administracyj-

${ }^{2}$ Z. Kmieciak, [w:] W. Chróścielewski, K. Defecińska-Tomczak, A. Korzeniowska, A. Kubiak-Kozłowska, Z. Kmieciak (red.), Polskie sqdownictwo administracyjne, Warszawa 2006, s. 2-3. 
nemu na orzekanie merytoryczne lub na zobowiązanie organu administracji publicznej do wydania orzeczenia określonej treści (dodanie art. $145 \S 3$, art. 145a ww. ustawy) ${ }^{3}$.

Modele sadownictwa administracyjnego można również podzielić ze względu na liczbę instancji. Zazwyczaj występuje trójinstancyjne sądownictwo (Francja, Holandia) oraz dwuinstancyjne (Niemcy, Polska). Trójinstancyjny model wydłuża kontrolę rozstrzygnięć $\mathrm{w}$ sprawach podatkowych, ale pozwala na bardziej wszechstronną ocenę zapadłych orzeczeń. Natomiast model dwuinstancyjny znacznie skraca etap sądowej kontroli spraw podatkowych i zmusza sąd ostatniej instancji do większej wnikliwości w rozpoznawaniu odwołań od orzeczeń sądów niższej instancji.

Poza tym w większości państw przyjęte rozwiązania prawne mogą być kontrolowane przez trybunały konstytucyjne poszczególnych państw (Polska, Niemcy) bądź Sąd Najwyższy (Stany Zjednoczone), do kompetencji którego należy zbadanie obowiązującego prawa pod względem zgodności z konstytucją. Zapadłe orzeczenia o niezgodności z konstytucją rozwiązań prawnych związanych z opodatkowaniem pozwalają wyeliminować z obrotu prawnego niekorzystne uregulowania prawne. Orzecznictwo trybunałów konstytucyjnych wpływa na poprawę procesu legislacji poszczególnych państw, ale także sprzyja dokonywaniu przez sądy rozstrzygające sprawy podatkowe wykładni prokonstytucyjnej, mającej na celu ochronę praw podatnika.

Istotną rolę w ochronie praw człowieka odgrywa Europejski Trybunał Praw Człowieka w Strasburgu (dalej: ETPCz). Niestety, orzecznictwo tego Trybunału konsekwentnie odmawia udzielania ochrony podatnikom. Takie rozstrzygnięcia wynikają zapewne z dużej liczby spraw (ok. 130000 zaległych) i z chęci uniknięcia napływu kolejnych. Jednak uregulowania zawarte w Europejskiej Konwencji Praw Człowieka często znajdują swoje odzwierciedlenie w prawie wewnętrznym poszczególnych państw i mogą wpływać na rozstrzygnięcia sądów państwa podatnika.

Ogromną rolę w ochronie praw podatnika odgrywa Trybunał Sprawiedliwości Unii Europejskiej w Luksemburgu (dalej: TS UE). Sądy krajowe, które funkcjonują w ramach Unii Europejskiej, mogą występować z pytaniami prejudycjalnymi, a w określonych sytuacjach strona może zwrócić się ze skargą do TS UE. W związku z tym orzeczenia TS UE wyznaczają w sprawach podatkowych, zwłaszcza dotyczących podatków podlegających harmonizacji, sposób wykładni stosowanej przy dokonywaniu sądowej kontroli.

${ }^{3}$ Projekt ustawy o zmianie ustawy Prawo o postępowaniu przed sądami administracyjnymi, przesłany przez Prezesa NSA do Prezydenta RP. 


\section{Sądy finansowe}

Ze względu na konieczność zapewnienia wysokiego profesjonalnego zabezpieczenia praw podatnika wydzielenie sądów finansowych do rozstrzygania spraw podatkowych daje najbardziej optymalną ochronę.

Taki system sądowy występuje w Niemczech, Portugalii i Nigerii. Sądownictwo finansowe w Republice Federalnej Niemiec posiada bogatą tradycję. Stanowi ono jeden z pięciu rodzajów jurysdykcji i jest w pełni niezależne od administracji skarbowej. Przewidziano w tym systemie dwie instancje. W pierwszej instancji dla każdego kraju (landu) jest co najmniej jeden sąd finansowy, mający status wyższego sądu rejonowego. Federalny Sąd Finansowy orzeka jako sąd odwoławczy. Omawiane sądy wydają orzeczenia we wszystkich sprawach podatkowych, które są regulowane prawem federalnym oraz w których administrują federalne lub krajowe organy podatkowe. Po wniesieniu sprawy do sądu finansowego i jej zarejestrowaniu odbywa się posiedzenie pojednawcze, które służy polubownemu załatwieniu sprawy. Finansowe Sądy Niemieckie słyną $\mathrm{z}$ dużej liczby załatwianych spraw $\mathrm{w}$ formie ugody (ok. 30\% spraw). Orzeczenie zapada po przeprowadzeniu ustnej rozprawy. W wydaniu orzeczenia uczestniczą nieprofesjonalni sędziowie. Strona może wnieść apelację do Federalnego Sądu Podatkowego w Hamburgu pod warunkiem, że sąd pierwszej instancji nie sprzeciwił się takiej apelacji. Przyjęcie apelacji do rozpoznania następuje, gdy zagadnienie prawne ma fundamentalne znaczenie ze względu na rozwój prawa lub zapewnienie jednolitego orzecznictwa i wymaga decyzji Federalnego Sądu Finansowego lub gdy naruszenie procedury, które zostało zaskarżone i istnieje, jest związane z wydaną decyzją ${ }^{4}$.

W 2007 r. powstał Nigeryjski Podatkowy Trybunał Apelacyjny, który jest podzielony na osiem stref. Każdą z nich kieruje przewodniczący oraz czterech członków, którzy niekoniecznie muszą być prawnikami, ale powinni mieć rozległą wiedzę z zakresu prawa podatkowego, administracji podatkowej i praktykę. Osoba poszkodowana może wnosić na odpowiednim formularzu odwołanie do Podatkowego Trybunału Apelacyjnego. Wspomniany sąd wydaje decyzje dopiero po przeprowadzeniu rozprawy. Od orzeczenia sądu przysługuje apelacja do Wyższego Sądu Federalnego, a następnie do Sądu Najwyższego Nigerii ${ }^{5}$.

${ }^{4}$ Ch. Schoenfeld, The Fiscal Court Process, [w:] Hamburg Fiscal Court. A court portrait, Hamburg 2009, s. 20-27.

${ }^{5}$ C. J. Amasie, Brief notes on the adjudication of tax disputes in Nigeria: the Tax Appeal Tribunal Perspective. 


\section{Model ochrony praw podatnika $w$ ramach sądownictwa administracyjnego}

Ojczyzną administracji jest Francja. Sprawy podatkowe rozpatrują sądy administracyjne, które składają się z trzech instancji, takich jak: trybunały administracyjne, sądy administracyjne apelacyjne i Rada Stanu. Sąd pierwszej instancji rozpatruje wszystkie sprawy podatkowe, sąd apelacyjny - odwołania od tych spraw za wyjątkiem spraw dotyczących podatków lokalnych, a Rada Stanu jest sądem kasacyjnym. Co charakterystyczne, sądy administracyjne we Francji mogą wydawać orzeczenia merytoryczne ${ }^{6}$.

Inaczej przedstawia się ochrona praw podatników w Polsce. Ma ona charter dwuinstancyjny. Dla każdego województwa utworzono sąd administracyjny. Od rozstrzygnięć kończących postępowanie przed pierwszą instancją przysługuje skarga kasacyjna do Naczelnego Sądu Administracyjnego, która ma częściowo charakter apelacji. Przedmiotem kontroli sądowej oprócz indywidualnych aktów administracyjnych $\mathrm{w}$ sprawach podatkowych i kontroli aktów prawa miejscowego dotyczących podatków lokalnych są również indywidualne interpretacje podatkowe ministra finansów. Poza tym sądy administracyjne dokonują kontroli aktów administracyjnych pod kątem legalności i w tym zakresie wydają jedynie orzeczenia o charakterze kasacyjnym.

\section{Model sądowej kontroli działający w ramach sądownictwa powszechnego}

Taki model kontroli spraw podatkowych występuje m.in. w Holandii. Nie ma wyspecjalizowanych sądów administracyjnych albo sądów podatkowych. W Holandii wymiar sprawiedliwości sprawują:

- Sąd Najwyższy (Hoge Raad) w liczbie 1;

- Sąd Apelacyjny (Gerechtshof) w liczbie 5;

- Sąd Okręgowy (Arrondissementsrechtbank) w liczbie 19.

Każdy sąd ma oddzielne izby podatkowe: liczba izb zależy od liczby spraw, którymi ma się dany sąd zajmować. Izba podatkowa Sądu Okręgowego i Sądu Apelacyjnego liczy trzech profesjonalnych sędziów, dwóch sędziów (raadsheer) i prezesa (wiceprezesa) - ten ostatni jest sędzią przewodniczącym. Nie występują lawnicy $\mathrm{w}$ sprawach podatkowych. Izby podatkowe tych trzech instancji sądowych tworzą profesjonalni sędziowie specjalizujący się w podatkach. Sędziowie Sądów Okręgowych orzekają w składach jedno- albo trzyosobowych; sędziowie

6 J. Borkowski, Rozdziat VI. Francja, [w:] Z. Kmieciak (red.), Postępowanie administracyjne w Europie, wyd. 2, Warszawa 2010, s. 175. 
Sądów Apelacyjnych w składach trzyosobowych; sędziowie Sądu Najwyższego w składach trzy- i pięcioosobowych w zależności od wagi sprawy.

\section{Model mieszany sądownictwa}

Model taki występuje w wielu krajach, m.in. w Czechach. W pierwszej instancji skargi na decyzje organów administracji rozpatrują wskazane wydziały sądów okręgowych - przy czym nie w każdym wypadku są to wydziały wyspecjalizowane $\mathrm{w}$ sprawach administracyjnych, a tym bardziej w sprawach podatkowych, bowiem przydział spraw zależy od wewnętrznej organizacji sądu. Od orzeczeń sądów okręgowych w sprawach podatkowych przysługuje skarga kasacyjna do Naczelnego Sądu Administracyjnego w Republice Czeskiej z siedzibą w Brnie. W Departamencie Orzeczniczym tego sądu skargi kasacyjne rozpatrywane są w Wydziale Finansowym przez sędziów wyspecjalizowanych w sprawach podatkowych ${ }^{7}$.

\section{Quasi-sądy podatkowe}

Jako przykład organu pomocnego przy rozwiązywaniu sporów podatkowych można wymienić Trybunał Podatkowy funkcjonujący w Danii. Jest on najwyższym administracyjnym organem odwoławczym w sprawach dotyczących opodatkowania, VAT, innych powinności, ceł, opłat rejestracyjnych samochodów i wyceny nieruchomości. Trybunał rozpatruje odwołania (apelacje) od lokalnych kolegiów odwoławczych (local appeal boards) w tzw. zwykłych sprawach podatkowych; od regionalnych organów podatkowych (regional tax authorities) w sprawach dotyczących przedsiębiorstw oraz od Krajowej Rady Podatkowej (National Assessment Council) w bardziej skomplikowanych sprawach. Tylko podatnicy, a nie organy podatkowe, mogą wnosić sprawy przed Trybunał Podatkowy. Trybunał Podatkowy nie jest sądem, chociaż posiada wiele podobieństw. Trybunał Podatkowy podejmuje decyzje w około 4500 spraw każdego roku. W skład trybunału wchodzą: prezes, trzech przewodniczących oraz 30 członków zewnętrznych - 19 członków wyznacza Minister Podatków (Minister of Taxation), 11 członków jest wybieranych przez parlament. Prezes, przewodniczący i co najmniej 11 członków musi spełniać wymogi dla bycia sędziami Sądu Najwyższego. 11 zewnętrznych członków to sędziowie w sądach najwyższej instancji albo w sądach okręgowych.

${ }^{7}$ Informacja o Naczelnym Sądzie Administracyjnym Republiki Czeskiej złożona w ramach Polsko-Czeskiej Grupy Roboczej o wzajemnej współpracy. 
Pozostali członkowie reprezentują duńskie społeczeństwo, będąc członkami parlamentu albo innymi politykami oraz przedstawicielami różnych organizacji reprezentujących handel, przemysł, pracowników, rolników, rzemieślników itp. Sprawy rozstrzyga się w składzie: jeden przewodniczący i dwóch albo trzech pozostałych członków. Sekretariat służy pomocą przy prowadzeniu spraw i zatrudnia ok. 60 starszych i młodszych stażem prawników. Trybunał Podatkowy ma obowiązek badać sprawy z własnej inicjatywy, dlatego może wyznaczać spotkania z podatnikami oraz ich przedstawicielami, przeglądać dokumentację i księgi rachunkowe. W większości spraw podatnik jest reprezentowany przez radcę prawnego. Decyzje są wydawane na podstawie pisemnego materiału. Ustna procedura ma miejsce w bardziej skomplikowanych sprawach na żądanie podatnika albo jego przedstawiciela. Sprawy karne i oszustwa podatkowe są rozstrzygane tylko przed sądami powszechnymi, a nie przed Trybunałem Podatkowym ${ }^{8}$.

\section{Kognicja Europejskiego Trybunału Praw Czlowieka w Strasburgu w sprawach podatkowych}

Jak już wcześniej wspomniano, ETPCz zajął stanowisko odnośnie braku kompetencji Trybunału w sprawach podatkowych. W wyroku z dnia 12 lipca 2001 r., nr skargi 44759/98, w sprawie Ferrazzini przeciwko Włochom uznano, że sprawa podatkowa nie należy do spraw z katalogu spraw cywilnych określonych w art. 6 ust. 1 Europejskiej Konwencji Praw Człowieka. W uzasadnieniu orzeczenia stwierdzono, że prawa i obowiązki nie muszą mieć zawsze charakteru cywilnego. W dziedzinie podatków zmiany, które mogły zajść w demokratycznych społeczeństwach, nie zmieniły fundamentalnego obowiązku płacenia podatku. Sprawy podatkowe wciąż należą do głównych prerogatyw władz publicznych, z przeważającą publiczną naturą stosunków między podatnikiem i organem podatkowym. Ze względu na to, że konwencje i protokoły należy interpretować jako całość, Trybunał zwrócił uwagę, że art. 1 protokołu nr 1 dotyczy ochrony własności, zastrzega prawo państwa do stosowania takiego prawa, jakie uzna za konieczne w celu zabezpieczenia uiszczania podatków. W konkluzji stwierdzono, że spory podatkowe wykraczają poza granice praw i obowiązków cywilnych, niezależnie od skutków finansowych, które nieuchronnie wynikają z nich dla podatnika ${ }^{9}$. W świetle omawianego orzeczenia ETPC sprawy podatkowe mogą nie

${ }^{8}$ Materiały uzyskane od Międzynarodowego Stowarzyszenia Sędziów Podatkowych dzięki uprzejmości członka Zarządu tego stowarzyszenia, sędzi Wojewódzkiego Sądu Administracyjnego we Wrocławiu Dagmary Dominik-Ogińskiej.

${ }^{9}$ M. A. Nowicki, Nowy Europejski Trybunat Praw Człowieka. Wybór orzeczeń 1999-2004, Zakamycze-Kraków 2005, s. 562-565. 
podlegać ochronie przewidzianej w art. 6 ust. 1 Konwencji. Jednak wyrok ten nie zapadł jednogłośnie i być może w przyszłości orzecznictwo będzie ewoluowało powrotem do udzielenia ochrony podatnikom na podstawie wskazanego uregulowania prawnego ${ }^{10}$.

\section{Rola Trybunału Sprawiedliwości Unii Europejskiej w ksztaltowaniu wykładni prawa podatkowego}

Ważną rolę w kształtowaniu wykładni prounijnej w państwach-członkach Wspólnoty Europejskiej odgrywa dotychczasowy dorobek orzecznictwa Trybunału Sprawiedliwości Unii Europejskiej. Wskazana wykładnia to proces interpretacji prawa sprzyjający prawu europejskiemu, zgodna z nim. W przypadku konfliktu między wykładnią prounijną a opartą na prawie krajowym pierwszeństwo ma wykładnia prounijna, oczywiście z pewnymi wyjątkami. Poza tym sądy zajmujące się sprawami podatkowymi mogą, a sądy ostatniej instancji powinny występować z pytaniami prejudycjalnymi do Trybunału Sprawiedliwości Unii Europejskiej - art. 13 Traktatu Unii Europejskiej.

Wyroki TS UE wpływają na orzecznictwo sądów zajmujących się sprawami podatkowymi, praktykę organów podatkowych i zachowanie podatników. Ponadto odgrywają one niebagatelną rolę w procesach legislacyjnych, wymuszając nowelizację ustaw. W przypadku negatywnych rozstrzygnięć dla poszczególnych państw wywołują one również konsekwencje finansowe dla budżetu tych państw.

Do zadań sądów zajmujących się sprawami podatkowymi w procesie badania legalności działań administracji podatkowej należy ocena rozwiązań legislacyjnych obowiązujących w państwach Unii Europejskiej pod kątem ich zgodności z prawem europejskim. Nie mniej istotnym zagadnieniem jest analiza praktyki stosowania przepisów prawa podatkowego przez organy podatkowe pod względem stosowania wykładni prounijnej. Kolejnym ważnym instrumentem zapewniającym efektywność prawa europejskiego jest występowanie z pytaniami prejudycjalnymi do Trybunału Sprawiedliwości Unii Europejskiej, a następnie wykonywanie zapadłych orzeczeń. Większość orzeczeń TS UE w sprawach podatkowych dotyczy podatków podlegających harmonizacji, tj. podatków od wartości dodanej i akcyzy. W sprawach tych Trybunał często pozostawia sądowi krajowemu ostateczną ocenę zgodności rozwiązań z prawem unijnym.

10 A. Mudrecki, Prawo podatnika do rozpoznania sprawy bez uzasadnionej zwłoki przed sadami administracyjnymi, [w:] J. Głuchowski, A. Pomorska, J. Szołno-Koguc (red.), Główne wyzwania i problemy systemu finansów publicznych, Lublin 2009, s. 597. 


\section{Podsumowanie}

Modele sądowej ochrony praw podatnika w świecie są bardzo zróżnicowane. W większości państw wybrano model ochrony sprawowany w ramach jurysdykcji sądów administracyjnych. Poza tym sprawy podatkowe są rozstrzygane w sądach powszechnych. Do wyjątku należy wyspecjalizowane sądownictwo podatkowe, które - w mojej ocenie - gwarantuje największą ochronę, gdyż zapewnia wysoką specjalizację sędziów załatwiających te sprawy.

W sądach występują dwa modele orzekania, tj. model orzekania merytorycznego oraz model orzekania weryfikacyjnego, co do zasady kasacyjnego. W Polsce rozważa się możliwość wprowadzenia częściowego modelu orzekania merytorycznego, aby zapobiec przewlekłości postępowania ${ }^{11}$.

Poza tym ze względu na liczbę instancji sądy administracyjne można podzielić na trójinstancyjne i dwuinstancyjne.

Należy ubolewać, że Trybunał Praw Człowieka w Strasburgu konsekwentnie odmawia zajęcia się sprawami podatkowymi.

W państwach Unii Europejskiej istotny wpływ na orzecznictwo sądów krajowych w sprawach podatkowych wywiera Trybunał Sprawiedliwości Unii Europejskiej.

$\mathrm{Na}$ tle przedstawionych modeli sądownictwa podatkowego można uznać, że przyjęte $\mathrm{w}$ Polsce rozwiązania mieszczą się wśród dominujących sposobów występujących w świecie. Przyjęty w Polsce model rozstrzygania spraw podatkowych w ramach wyodrębnionego sądownictwa administracyjnego przy stosowaniu kasacyjnego sposobu rozstrzygania sporu daje gwarancję ochrony praw podatnika na podstawowym poziomie. Nie oznacza to, że system ten nie powinien być monitorowany i zmieniany. Istotną rolę w ocenie jakości orzecznictwa i poziomu ochrony praw podatnika może odgrywać merytoryczne przygotowanie sędziów orzekających w tych sprawach.

${ }^{11}$ Materiały II. seminarium eksperckiego w zakresie „Obywatel wobec administracji”, www. prezydent.pl/dialog/fdp/sprawne-i-sluzebne-panstwo/materialy. 